\title{
Evaluation of Sub-Soil Geotechnical Properties for Shallow Foundation and Pavement Design in LASPOTECH, Ikorodu Campus, Lagos State, Nigeria
}

\author{
Adigun Muritala $\mathrm{A}^{1}$, Olatunji Kayode $\mathrm{A}^{2}$, Alaboru Favour $\mathrm{O}^{3}$ and Ogunbajo \\ Abdulhakeem $\mathrm{B}^{4}$ \\ Civil Engineering Department, Lagos State Polytechnic, Ikorodu, Lagos State, Nigeria
}

\begin{abstract}
Sequel to continuous failure of structures all over the country, adequate knowledge of the geotechnical characteristics of underlying soils at construction sites has become very desirable for foundation design and construction of civil engineering structures. This study aims at investigating and establishing the sub-soil types and profile to determine the engineering characteristics of the underlying soils within the Ikorodu Campus of the Lagos State Polytechnic, Ikorodu, Lagos, Nigeria and recommend appropriate foundation and road pavement design. Forty Dynamic Cone penetrometer tests were performed alongside eight borings which were accomplished using percussion rig with augers. Representative soil samples were obtained and analyzed in the laboratory in accordance with relevant geotechnical engineering standards. Result of the study showed that the study area was found to consist of about $0.35 \mathrm{~m}$ thick of organic top soil followed by $9 \mathrm{~m}$ thick of reddish lateritic sandy clay. The study also revealed that the superficial lateritic soil has a bearing capacity ranging from $130 \mathrm{kN} / \mathrm{m}^{2}$ at $1.0 \mathrm{~m}$ depth to $243 \mathrm{kN} / \mathrm{m}^{2}$ at $2.5 \mathrm{~m}$ depth. Shallow foundation with bearing capacity of $150 \mathrm{kN} / \mathrm{m}^{2}$ at footing depth not lower than $1.2 \mathrm{~m}$ is recommended for general use within the campus. Maximum expected settlement is estimated at $27.84 \mathrm{~mm}$. Similarly, a CBR value of $7 \%$ is recommended as subgrade CBR value for road pavement design within the campus.
\end{abstract}

Keywords: Geotechnical Properties, Subsurface-soils,, Foundation Design, Pavement Design, CBR.

\section{Introduction}

Records and investigations have shown that many of the stakeholders in the building construction industry have not been paying adequate attention to the role of geotechnical information in the planning, design, construction, operation and safety of civil engineering infrastructures. This neglect has been discovered as one of the sources of failure of structures [1 \& 2]. Frequent structural failure of civil engineering infrastructures in parts of Lagos Metropolis has become a source of worry to the government, engineering organizations as well as many individuals, hence, a good understanding of the occurrence, composition, distribution, geologic history as well as the geotechnical properties of subsurface soils in the areas where structures are to be erected is necessary.

Lagos State as a whole occurs within an area underlain by sedimentary deposits of the Dahomey Basin which is constituted of five sedimentary formations, viz: the Abeokuta Formation; composed of sands and sandstones with clays, the Ewekoro Formation; composed of Limestones, clays and shales, the Ilaro Formation; composed of Shales and Clays with few sand lenses, the Coastal Plains Sands; composed of sands, silts, clays and traces of peat and the recent alluvial deposits; composed of soft clays, peat and loose sand[3].

In the desire to have a good design and construction of foundation of future civil engineering structures in order to minimize adverse effects and prevention of post construction problems, some general studies have been carried out on geotechnical properties of the sub-soils [4]. To obtain relevant data inputs for the design and construction of foundations for proposed structures, it is important that construction site be geo-technically characterized carrying out sub-soil investigation. This paper therefore, aims at establishing significant subsoil types and profile, investigation of the engineering characteristics of all such sub-soils to generate the required data relevant to the foundation design and construction of structures within the Ikorodu campus of Lagos State Polytechnic.

\section{Description of the Study Area}

Lagos State is an integral part of Nigeria coastal plain and extended Nigeria continental shelf. The deposits are therefore, geologically young, ranging from the Eocene to the recent Pliocene. The soils are mainly alluvial mix with sand, clay, peat and silt in various proportions. The state has an annual rainfall of $1185 \mathrm{~mm}$. The territory lies in typical West African Continental shelf with beaches and bars draining into the big sea. [5].

The project area is located within Ikorodu Local Government Area of Lagos State, Nigeria (Fig. 1) lies within the transitional zone between the Precambrian basement complex rocks of the southwestern Nigeria and 
the cretaceous sediments of the Abeokuta group in the eastern part of the Dahomey Basins. The basement rocks occurs predominantly in the north, northwest and northeastern part of the field and it is predominantly a Migmatite gnesis complex of biotite granite gnesiss, biotite hornblende gnesiss with varying degrees of fracturing [3]. The southern part of the field is overlain by Ise member of Abeokuta group that conformably overlies the basement rocks. Litho-stratigraphically, Abeokuta group comprises of grits, arkosic sandstone, siltstone and clay with occasional conglomerate of predominantly arenaceous materials. [4]

The clay in the area is mainly residual clay, deposited over the basement complex rocks of the project area. The residual clay was formed by surface weathering, which gives rise to clay by the chemical decomposition of the rocks, containing silica and alumina.

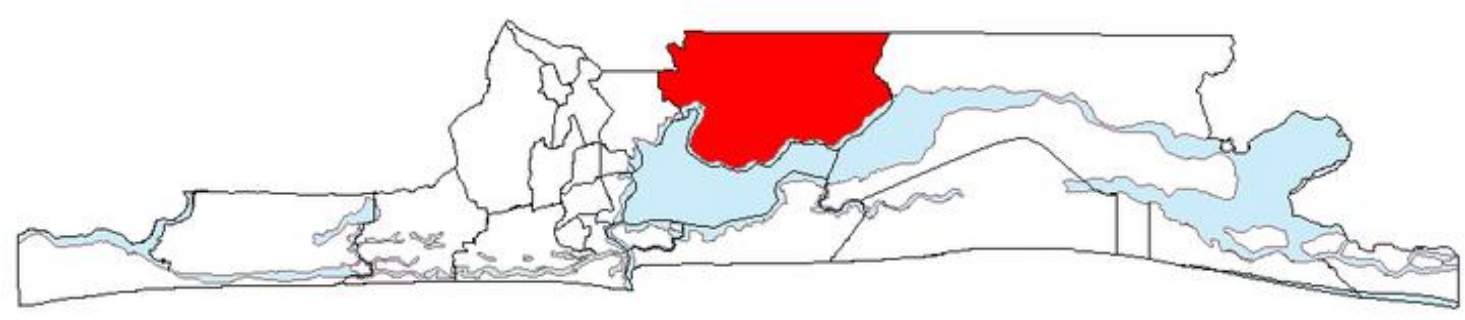

Figure 1 Map of Lagos State showing Ikorodu L.G.A

\subsection{Field Investigation}

\section{Methodology}

Field investigation and laboratory tests were conducted to obtain information on the underlying soils within the study area. The field investigations consist of various field activities carried out between end of 2012 and 2014. The field activities include six (8) numbers borings (BH 1 to BH 8) and 40 numbers Dynamic Cone Penetrometer Tests spread across the campus. Fig. 2 shows the campus general layout of the study area. [6].

The borings were accomplished using a light cable percussion (shell and auger) technique with a fully equipped motorized Dando 150 drilling rig. The Boring Tests were accompanied by disturbed and undisturbed samples. The field investigation revealed that closest groundwater level was at $9.00 \mathrm{~m}$ below the ground surface. Soil samples were obtained and carefully prepared in the field and were transported to the laboratory for further visual inspection and laboratory testing to establish their physical and engineering properties.

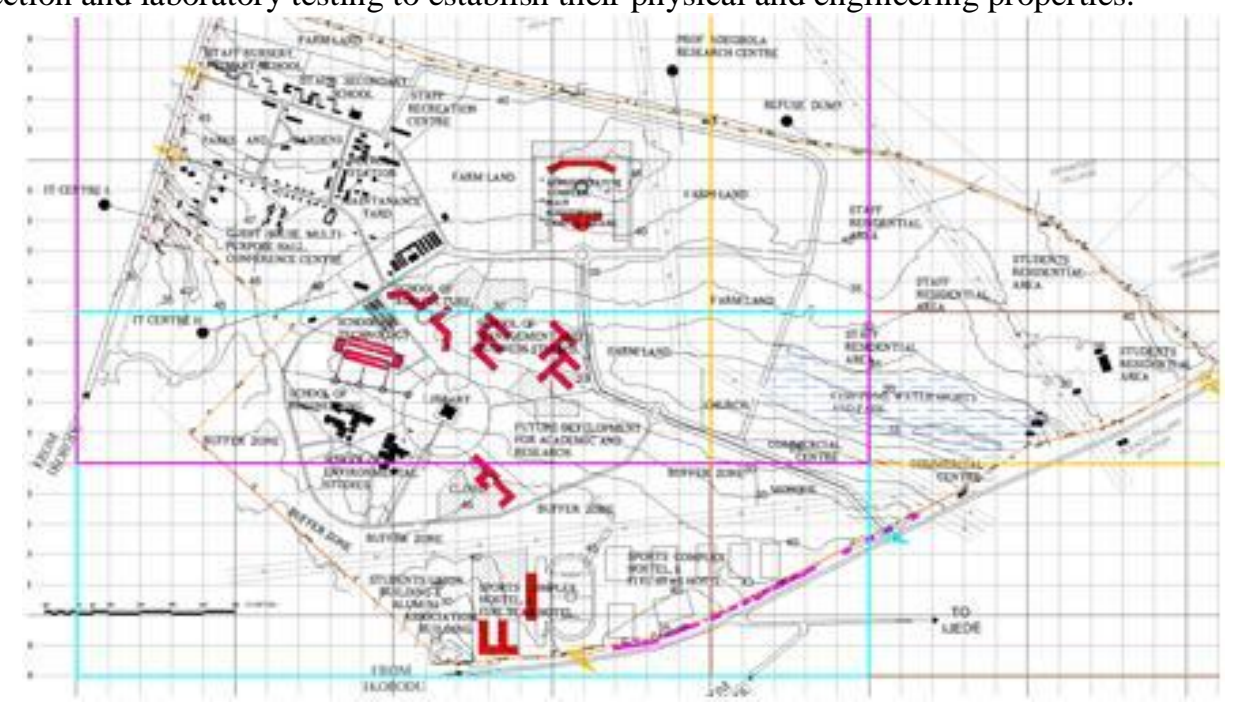

Figure 2. Plan of Lagos State Polytechnic

\subsection{Laboratory Testing}

All samples obtained in the field were carefully preserved and subjected to more detailed visual inspection and descriptions at the laboratory. Thereafter, representative samples were selected from each stratum for laboratory analysis in accordance with relevant geotechnical engineering standards including BS 1377; 1990. [7].The disturbed soil samples were appropriately subjected to the following laboratory classification tests:(i) Natural moisture content (ii) Atterberg limits (liquid and plastic limits).(iii)Grain size analysis. Sieve analysis of cohesive soils were done by soaking oven-dried samples in water overnight and washing through sieve No. 200 
(75 microns opening) while remnants retained on sieve No. 200 were oven-dried and sieved mechanically. Materials finer than sieve number 200 were analysed using the hydrometer method based on Stoke's Law.

The undisturbed and mostly cohesive samples collected in the course of boring were subjected to:

(i) Unconsolidated Undrain triaxial tests at cell pressures of $100 \mathrm{kPa}$, and $300 \mathrm{kPa}$; and (ii) Oedometer consolidation test. The shear strength parameters $c_{u}$ and $\varphi_{u}$ of the cohesive soil samples were obtained from the Unconsolidated Undrain triaxial test, while shear strength parameter of the granular soils were evaluated from average SPT-number of the respective stratum. The results of the physical engineering properties are presented in TABLE 1.

The formula developed by Terzaghi [8] has been adopted in estimating the soil bearing pressure. The bearing capacity equation (1) for rectangular footing, equation was used in computing the bearing capacity for shallow foundation:

$\mathrm{q}_{\mathrm{u}}=$ Ultimate bearing capacity

$$
\mathrm{q}_{\mathrm{u}}=\mathrm{cN}_{\mathrm{c}}\left(1+0.3 \frac{\mathrm{B}}{\mathrm{L}}\right)+\gamma \mathrm{D}_{\mathrm{f}} \mathrm{N}_{\mathrm{q}}+0.5 \gamma B \mathrm{~N}_{\gamma}\left(1-0.2 \frac{\mathrm{B}}{\mathrm{L}}\right)
$$

$\mathrm{c}=$ Undrained cohesion of soil

$\mathrm{Y}=$ Unit weight of soil

$\mathrm{D}_{\mathrm{f}}=$ Footing depth

$\mathrm{B}=$ Breadth of foundation

$\mathrm{L}=$ Length of foundation

$\mathrm{N}_{\mathrm{c}}, \mathrm{N}_{\mathrm{q}}, \mathrm{N}_{\gamma}=$ bearing capacity factors that are non-dimensional and are only functions of the soil friction angle, $\phi$

The allowable bearing capacity of the soil has been evaluated with a factor of safety (F.S) of 3.0 and a summary of the allowable bearing capacity are presented in TABLE 2 .

\subsection{Settlement Analysis}

Total consolidation settlement $\left(\rho_{\mathrm{c}}\right)$ has been computed for foundation breadth (B) between 1.002.50 metres, subjected to a allowable bearing capacity of $150 \mathrm{kN} / \mathrm{m}^{2}$.

Based on the soil lithology, the thickness of the consolidating layer for a square foundation is taken as the depth to the point where the induced vertical stress $(\Delta \sigma)$ is equal to $0.55 \mathrm{qn}$. The induced vertical stress $(\Delta \sigma)$ at the centre of the consolidating layer has been used in computing $\rho_{\mathrm{c}}$. The consolidation settlement has been computed from the expression below. [9].

$$
\rho_{\mathrm{v}}=\mu_{\mathrm{g}} \mathrm{P}_{\text {oed }}=\mathrm{m}_{\mathrm{v}} \sigma_{\mathrm{z}} \mathrm{H}=\mathrm{m}_{\mathrm{v}} \times 0.55 \mathrm{q}_{\mathrm{n}} \times 1.5 \mathrm{~B}
$$

where $\mu_{\mathrm{g}}=$ Coefficient which depends on the type of clay

$\mathrm{P}_{\text {oed }}=$ Settlement as calculated from oedometer test

$\mathrm{m}_{\mathrm{v}}=$ Coefficient of volume compressibility

$\mathrm{q}_{\mathrm{n}}=$ Net foundation pressure

$\mathrm{B}=$ Breadth of foundation.

An $\mathrm{m}_{\mathrm{v}}$ value of $0.075 \mathrm{~m}^{2} / \mathrm{MN}$, which corresponds to the adopted net allowable bearing capacity was used in the settlement analysis. The results are presented in TABLE 3

\subsection{The Dynamic Cone Penetrometer tests (DCP)}

A total number of forty (40) DCP tests distributed over the developing sections of the study area were performed. The entire area were sub-divided into eight (8) sections. Four to six DCPT tests were carried out in each section depending on size. The average data from each section DCP tests were processed to produce penetration index (PI), which is simply the distance the cone penetrates with each drop of the hammer. The PI is expressed in terms of millimeters per blow. The results were then used to estimate the subgrade California Bearing Ratio (CBR). The Data from these tests have been analyzed using the relationship developed by Transport and Road Research Laboratory. [10].

$$
\log _{10}[\mathrm{CBR}]=2.48-1.057 \log _{10}[\mathrm{PI}]
$$

The results of the DCP tests and calculated values of CBR are presented in TABLE 4

\subsection{Soil Stratigraphy}

\section{Results}

The data obtained from the boring, soil sampling, field penetration tests and laboratory tests were interpreted to determine the stratification of subsoils underlying the site. From borehole tests conducted, six subsoil zones have been delineated. This first zone (topsoil) consists of the light brown lateritic/sandy clay deposits intermingled with roots and thickness of about $0.35 \mathrm{~m}$. The second zone is a reddish Lateritic sandy clay deposit occurring from depths of $0.35 \mathrm{~m}$ to $9.75 \mathrm{~m}$. Underlying this layer is light mottled clayey silty sand deposit of about $6 \mathrm{~m}$ thick. This represents the third zone. The fourth zone in the soil profile is the firm to stiff mottled 
silt sandy clay deposit with average thickness of $3.75 \mathrm{~m}$. Underlying is the fifth zone comprising a layer of firm to stiff mottled silt sandy clay deposit. The thickness of this layer is about $2.25 \mathrm{~m}$. The sixth zone occurring between 21.75 and $30 \mathrm{~m}$ is a mottled sandy clay deposit.

\subsection{Physical and Engineering Properties of Sub-Soils}

The results of field and laboratory analysis of various samples of the soil superficially dominating the site through the boring depths show that the area of study is characterized by lateritic sandy clay within the upper $9.75 \mathrm{~m}$. Some selected physical and engineering properties of the soil materials is summarized in Table 1a and $1 \mathrm{~b}$.

\subsection{Bearing Capacity of soil}

The allowable bearing capacity of the soil at depths $1.0 \mathrm{~m}, 1.5 \mathrm{~m}$ and $2.5 \mathrm{~m}$ have been evaluated with factor of safety of 3.0. The summary of the net allowable bearing capacity are presented in Table 2. The variation of bearing capacity with foundation depth for square pad footing is depicted in Fig. 3

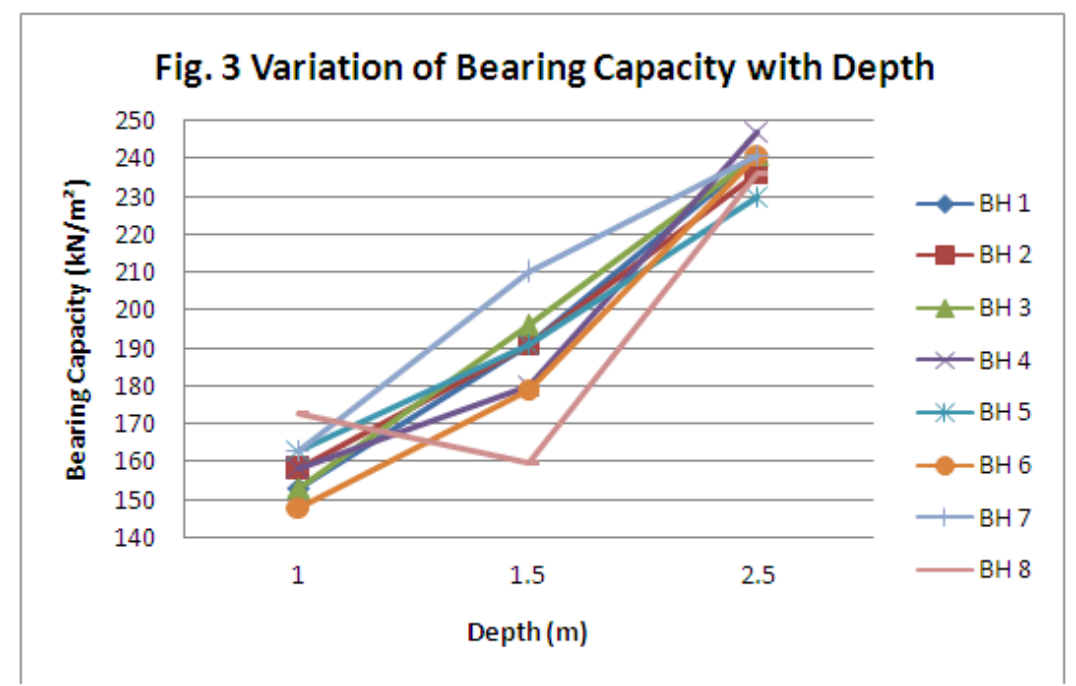

Figure 3. Variation of bearing capacity with depth

\subsection{Settlement of soil}

The results of the consolidation settlement for foundation breadth, B between $1.0 \mathrm{~m}$ and $3.0 \mathrm{~m}$ at the net allowable bearing pressure of $150 \mathrm{kN} / \mathrm{m}^{2}$ are presented in Table 3 .

\subsection{California Bearing Ratio (CBR) of subgrade soil}

The results of the dynamic cone penetrometer tests showing the penetration index and the corresponding CBR values are presented in Tables $4 \mathrm{a}$ to $4 \mathrm{~h}$.

\section{Discussions}

Results of the study revealed that the major sub-soils underlying the study area have about $0.35 \mathrm{~m}$ thick brown lateritic/sandy clay top soil which is followed by reddish Lateritic sandy clay which existed upto about $10 \mathrm{~m}$ depth underlain by clayey silty sand to a depth of around $16.0 \mathrm{~m}$ and silty sandy clay from this point to the end of boring at $30 \mathrm{~m}$. Appropriate type of shallow foundation will be adequate for expected structural loads within the campus since a medium to firm lateritic sandy clay existed upto a depth of about $10 \mathrm{~m}$ and is underlain by another medium to dense silty sand. The bearing capacity generally increases with depth from $130 \mathrm{kN} / \mathrm{m}^{2}$ at $1.0 \mathrm{~m}$ depth to $243 \mathrm{kN} / \mathrm{m}^{2}$ at $2.5 \mathrm{~m}$ depth. An average bearing capacity of $150 \mathrm{kN} / \mathrm{m}^{2}$ is estimated to be adequate and this could be used in determining the foundation type for structures within the campus.

The computed settlement values as presented for a shallow foundation with footing width between 1.00 $-3.00 \mathrm{~m}$ is less than the allowable maximum settlements suggested for isolated foundations on clays of $65 \mathrm{~mm}$. [11]. Hence the foundation can sustain the suggested allowable bearing pressure of $150 \mathrm{kN} / \mathrm{m}^{2}$.

The DCP tests results indicated that the first $200 \mathrm{~mm}$ to $400 \mathrm{~mm}$ layer which consists majorly of top soil is characterized with CBR value of $6.12 \%$ to $8.73 \%$. The soil layer below the top soil is characterized with a minimum CBR value of $7.42 \%$ and maximum CBR value of $14.08 \%$ between $400 \mathrm{~mm}$ and $1000 \mathrm{~mm}$ depth 
The results also show that penetration index values generally decreases with depth indicating increase in CBR with depth. The values of the CBR increases from $7.42 \%$ at $400 \mathrm{~mm}$ depth to a maximum CBR value of about $18.17 \%$ at $2000 \mathrm{~mm}$ depth.

\section{Conclusion}

Upon removal of the organic top soil, the superficial lateritic sandy clay is found suitable in quality to sustain shallow foundation loads by low to medium rise structures. It also possesses enough thickness to completely dissipate the influence of such foundations. An allowable bearing pressure of $150 \mathrm{kN} / \mathrm{m}^{2}$ is recommended for the campus for shallow foundations which could be placed between $1.2 \mathrm{~m}$ and $2.5 \mathrm{~m}$ depth. Expected maximum settlement is $27.84 \mathrm{~mm}$, this is less than the allowable maximum settlement of $65 \mathrm{~mm}$ for isolated foundation in clays. An average value of $7 \%$ is also recommended as CBR value for the subgrade layer. The pavement thickness of sub-base, base and surfacing should be dependent on this value. However, localized soft point(s) along the road route should be subjected to further and detailed investigation to obtain appropriate design parameters.

\section{References}

[1]. R.C Murat, (1970). Stratigraphy and Paleogeography of the Cretaceous and Lower Tertiary in Southern Nigeria (African Geology, University of Ibadan Press, Ibadan, Nigeria) 1970

[2]. A.N Amadi,; C.J Eze,; C.O Igwe,; I.A Okunlola, and N.O Okoye, Architect's and geologist's view on the causes of building failures in Nigeria. Modern Applied Science, Vol.6 (6), 2012, 31 - 38

[3]. A.I Olayinka,. and O.O Osinowo, Integrated geophysical and satellite imagery mapping for groundwater assessment in a geological transition zone in south-western Nigeria, SAGEEP, Vol. 22, 2009, pp977-987.

[4]. S.O Olabode and J.A Adekoya, Seismic stratigraphy and development of Avon canyon in Benin (Dahomey) basin, southwestern Nigeria, Journal of African Earth Sciences, Volume 50, Issue 5, 2008, Pages 286-304

[5]. E.O Longe, Groundwater Resources Potential in the Coastal Plain Sands Aquifers, Lagos, Nigeria, Research Journal of Environmental and Earth Sciences 3(1), 2011, 1-7

[6]. MASTER PLAN of Lagos State Polytechnic, Works Department, Lagos State Polytechnic, Ikorodu

[7]. British Standard Institutions, Methods of Test for soils for Civil Engineering Purposes. B.S 1377: Part 2, 1990. pp 8 - 200

[8]. K Terzaghi, Theoretical soil mechanics (John Willey, 1943)

[9]. M A Stroud, and F G Butler, The standard penetration test and the engineering properties of Glacial materials. In: Proceedings of the Symposium of glacial materials, University of Birmingham.1975

[10]. Transport and Road Research Laboratory, Road note 8, A user's manual for a program to analyse dynamic cone penetrometer data

[11]. A.W Skempton, and D.H MacDonald, The Allowable Settlement of Buildings, Proc. Inst. Of Civil Engineers, Part 3, Vol. 5, 1956, pp. 727-784.

Table 1a: Physical and Engineering properties of the soil

\begin{tabular}{|c|c|c|c|c|c|c|c|c|c|}
\hline \multirow[t]{2}{*}{ Properties } & \multirow[t]{2}{*}{ Depth (m) } & \multicolumn{8}{|c|}{ Mean Value at Test Point } \\
\hline & & 1 & 2 & 3 & 4 & 5 & 6 & 7 & 8 \\
\hline Natural Moisture content (\%) & $\begin{array}{l}1.00 \\
1.50 \\
2.50\end{array}$ & $\begin{array}{l}19 \\
21 \\
20\end{array}$ & $\begin{array}{l}21 \\
20 \\
20\end{array}$ & $\begin{array}{l}19 \\
19 \\
18\end{array}$ & $\begin{array}{l}19 \\
20 \\
18\end{array}$ & $\begin{array}{l}20 \\
22 \\
22\end{array}$ & $\begin{array}{l}20 \\
19 \\
20\end{array}$ & $\begin{array}{l}18 \\
21 \\
21\end{array}$ & $\begin{array}{l}20 \\
19 \\
19\end{array}$ \\
\hline Bulk Unit Weight $\left(\mathrm{kN} / \mathrm{m}^{3}\right)$ & $\begin{array}{l}1.00 \\
1.50 \\
2.50\end{array}$ & $\begin{array}{l}19.60 \\
19.82 \\
19.98\end{array}$ & $\begin{array}{l}19.40 \\
19.90 \\
20.01\end{array}$ & $\begin{array}{l}19.70 \\
19.50 \\
19.88\end{array}$ & $\begin{array}{l}19.94 \\
19.60 \\
19.75\end{array}$ & $\begin{array}{l}19.12 \\
19.65 \\
19.78\end{array}$ & $\begin{array}{l}19.80 \\
19.84 \\
20.15\end{array}$ & $\begin{array}{l}18.98 \\
19.24 \\
19.62\end{array}$ & $\begin{array}{l}19.81 \\
20.04 \\
20.08\end{array}$ \\
\hline Dry Unit Weight $\left(\mathrm{kN} / \mathrm{m}^{3}\right)$ & $\begin{array}{l}1.00 \\
1.50 \\
2.50\end{array}$ & $\begin{array}{l}16.47 \\
16.38 \\
16.65\end{array}$ & $\begin{array}{l}16.03 \\
16.58 \\
16.68\end{array}$ & $\begin{array}{l}16.55 \\
16.39 \\
16.85\end{array}$ & $\begin{array}{l}16.76 \\
16.33 \\
16.74\end{array}$ & $\begin{array}{l}15.93 \\
16.11 \\
16.21\end{array}$ & $\begin{array}{l}16.50 \\
16.67 \\
16.79\end{array}$ & $\begin{array}{l}16.08 \\
15.90 \\
16.21\end{array}$ & $\begin{array}{l}16.51 \\
16.84 \\
16.87\end{array}$ \\
\hline Effective Unit Weight $\left(\mathrm{kN} / \mathrm{m}^{3}\right)$ & $\begin{array}{l}1.00 \\
1.50 \\
2.50\end{array}$ & $\begin{array}{l}9.79 \\
10.01 \\
10.17\end{array}$ & $\begin{array}{l}9.59 \\
10.09 \\
10.20\end{array}$ & $\begin{array}{l}9.89 \\
9.69 \\
10.07\end{array}$ & $\begin{array}{l}10.13 \\
9.79 \\
9.94\end{array}$ & $\begin{array}{l}9.31 \\
9.84 \\
9.97\end{array}$ & $\begin{array}{l}9.99 \\
10.03 \\
10.34\end{array}$ & $\begin{array}{l}9.17 \\
9.43 \\
9.81\end{array}$ & $\begin{array}{l}10.00 \\
10.23 \\
10.27\end{array}$ \\
\hline Liquid Limit (\%) & $\begin{array}{l}1.00 \\
1.50 \\
2.50\end{array}$ & $\begin{array}{l}42 \\
42 \\
44\end{array}$ & $\begin{array}{l}44 \\
42 \\
41\end{array}$ & $\begin{array}{l}43 \\
41 \\
43\end{array}$ & $\begin{array}{l}41 \\
40 \\
42\end{array}$ & $\begin{array}{l}42 \\
39 \\
44\end{array}$ & $\begin{array}{l}44 \\
41 \\
44\end{array}$ & $\begin{array}{l}41 \\
42 \\
43\end{array}$ & $\begin{array}{l}40 \\
39 \\
40\end{array}$ \\
\hline Plastic Limit (\%) & $\begin{array}{l}1.00 \\
1.50 \\
2.50\end{array}$ & $\begin{array}{l}19 \\
19 \\
20\end{array}$ & $\begin{array}{l}21 \\
20 \\
21\end{array}$ & $\begin{array}{l}22 \\
19 \\
20\end{array}$ & $\begin{array}{l}20 \\
21 \\
22\end{array}$ & $\begin{array}{l}21 \\
19 \\
20\end{array}$ & $\begin{array}{l}22 \\
21 \\
22\end{array}$ & $\begin{array}{l}21 \\
19 \\
20\end{array}$ & $\begin{array}{l}20 \\
19 \\
21\end{array}$ \\
\hline Plasticity Index (\%) & $\begin{array}{l}1.00 \\
1.50 \\
2.50\end{array}$ & $\begin{array}{l}23 \\
23 \\
24\end{array}$ & $\begin{array}{l}23 \\
22 \\
20\end{array}$ & $\begin{array}{l}21 \\
22 \\
23\end{array}$ & $\begin{array}{l}21 \\
19 \\
20\end{array}$ & $\begin{array}{l}21 \\
20 \\
24\end{array}$ & $\begin{array}{l}22 \\
20 \\
22\end{array}$ & $\begin{array}{l}20 \\
23 \\
23\end{array}$ & $\begin{array}{l}20 \\
20 \\
19\end{array}$ \\
\hline Undrained Frictional Angle, $\left({ }^{\circ}\right)$ & $\begin{array}{l}1.00 \\
1.50 \\
2.50\end{array}$ & $\begin{array}{l}9 \\
11 \\
12\end{array}$ & $\begin{array}{l}10 \\
11 \\
12\end{array}$ & $\begin{array}{l}9 \\
11 \\
13\end{array}$ & $\begin{array}{l}11 \\
11 \\
13\end{array}$ & $\begin{array}{l}10 \\
11 \\
11\end{array}$ & $\begin{array}{l}9 \\
10 \\
12\end{array}$ & $\begin{array}{l}10 \\
12 \\
12\end{array}$ & $\begin{array}{l}11 \\
9 \\
11\end{array}$ \\
\hline
\end{tabular}


Evaluation of Sub-Soil Geotechnical Properties for Shallow Foundation and Pavement Design ....

\begin{tabular}{|c|c|c|c|c|c|c|c|c|c|}
\hline Undrained cohesion $\left(\mathrm{kN} / \mathrm{m}^{2}\right)$ & $\begin{array}{l}1.00 \\
1.50 \\
2.50\end{array}$ & $\begin{array}{l}28 \\
29 \\
31\end{array}$ & $\begin{array}{l}27 \\
29 \\
30\end{array}$ & $\begin{array}{l}28 \\
30 \\
31\end{array}$ & $\begin{array}{l}25 \\
27 \\
30\end{array}$ & $\begin{array}{l}28 \\
29 \\
32\end{array}$ & $\begin{array}{l}26 \\
29 \\
31\end{array}$ & $\begin{array}{l}28 \\
30 \\
31\end{array}$ & $\begin{array}{l}28 \\
29 \\
33\end{array}$ \\
\hline Void ratio & $\begin{array}{l}1.00 \\
1.50 \\
2.50\end{array}$ & $\begin{array}{l}0.56 \\
0.57 \\
0.54\end{array}$ & $\begin{array}{l}0.60 \\
0.55 \\
0.54\end{array}$ & $\begin{array}{l}0.55 \\
0.57 \\
0.53\end{array}$ & $\begin{array}{l}0.53 \\
0.57 \\
0.54\end{array}$ & $\begin{array}{l}0.61 \\
0.60 \\
0.59\end{array}$ & $\begin{array}{l}0.56 \\
0.54 \\
0.53\end{array}$ & $\begin{array}{l}0.60 \\
0.62 \\
0.59\end{array}$ & $\begin{array}{l}0.56 \\
0.53 \\
0.52\end{array}$ \\
\hline Specific Gravity & & 2.66 & 2.63 & 2.64 & 2.65 & 2.65 & 2.62 & 2.64 & 2.65 \\
\hline Effective particle size, $\mathrm{d}_{10}(\mathrm{~mm})$ & & 0.221 & 0.230 & 0.206 & 0.186 & 0.222 & 0.209 & 0.213 & 0.229 \\
\hline Effective particle size, $\mathrm{d}_{10}(\mathrm{~mm})$ & & 0.515 & 0.500 & 0.495 & 0.510 & 0.520 & 0.522 & 0.500 & 0.516 \\
\hline Effective particle size, $\mathrm{d}_{10}(\mathrm{~mm})$ & & 0.340 & 0.380 & 0.330 & 0.350 & 0.390 & 0.360 & 0.345 & 0.365 \\
\hline Coefficient of uniformity, $\mathrm{C}_{\mathrm{u}}$ & & 1.54 & 1.65 & 1.60 & 1.88 & 1.76 & 1.72 & 1.62 & 1.59 \\
\hline Coefficient of curvature, $\mathrm{C}_{\mathrm{c}}$ & & 4.33 & 3.33 & 3.99 & 3.11 & 3.10 & 3.46 & 3.79 & 3.79 \\
\hline Classification ( Unified) & & $\mathrm{CL}$ & $\mathrm{CL}$ & $\mathrm{CL}$ & $\mathrm{CL}$ & $\mathrm{CL}$ & $\mathrm{CL}$ & $\mathrm{CL}$ & $\mathrm{CL}$ \\
\hline
\end{tabular}

Table 2: Estimated Bearing Capacity

\begin{tabular}{|c|c|c|c|c|c|c|}
\hline BH No. & $\begin{array}{c}\text { Depth of Sample } \\
\text { (m) }\end{array}$ & $\begin{array}{l}\text { Unit Weight, } \gamma \\
\left(\mathrm{kN} / \mathrm{m}^{3}\right)\end{array}$ & $\begin{array}{c}\text { Frictional } \\
\text { Angle, } \varphi\left(^{\circ}\right)\end{array}$ & $\begin{array}{l}\text { Undrained } \\
\text { cohesion, c }\end{array}$ & $\begin{array}{l}\text { Breadth/ Length } \\
\text { ratio }\end{array}$ & $\begin{array}{c}\text { Allowable Bearing } \\
\text { Capacity, qu, }\left(\mathrm{kN} / \mathrm{m}^{2}\right)\end{array}$ \\
\hline \multirow{3}{*}{1} & 1.00 & 19.6 & 9 & 28 & $\begin{array}{l}0.50 \\
0.75 \\
1.00 \\
\end{array}$ & $\begin{array}{l}138 \\
145 \\
153 \\
\end{array}$ \\
\hline & 1.50 & 19.81 & 11 & 29 & $\begin{array}{l}0.50 \\
0.75 \\
1.00\end{array}$ & $\begin{array}{l}173 \\
182 \\
191\end{array}$ \\
\hline & 2.50 & 19.83 & 12 & 31 & $\begin{array}{l}0.50 \\
0.75 \\
1.00 \\
\end{array}$ & $\begin{array}{l}222 \\
232 \\
241 \\
\end{array}$ \\
\hline \multirow{3}{*}{2} & 1.00 & 19.6 & 10 & 27 & $\begin{array}{l}0.50 \\
0.75 \\
1.00\end{array}$ & $\begin{array}{l}142 \\
150 \\
158\end{array}$ \\
\hline & 1.50 & 19.81 & 11 & 29 & $\begin{array}{l}0.50 \\
0.75 \\
1.00\end{array}$ & $\begin{array}{l}173 \\
182 \\
191\end{array}$ \\
\hline & 2.50 & 19.83 & 12 & 30 & $\begin{array}{l}0.50 \\
0.75 \\
1.00\end{array}$ & $\begin{array}{l}217 \\
226 \\
236\end{array}$ \\
\hline \multirow{3}{*}{3} & 1.00 & 19.6 & 9 & 28 & $\begin{array}{l}0.50 \\
0.75 \\
1.00 \\
\end{array}$ & $\begin{array}{l}138 \\
145 \\
153 \\
\end{array}$ \\
\hline & 1.50 & 19.81 & 11 & 30 & $\begin{array}{l}0.50 \\
0.75 \\
1.00\end{array}$ & $\begin{array}{l}178 \\
187 \\
196\end{array}$ \\
\hline & 2.50 & 19.83 & 13 & 31 & $\begin{array}{l}0.50 \\
0.75 \\
1.00\end{array}$ & $\begin{array}{l}238 \\
249 \\
259\end{array}$ \\
\hline \multirow{3}{*}{4} & 1.00 & 19.6 & 11 & 25 & $\begin{array}{l}0.50 \\
0.75 \\
1.00 \\
\end{array}$ & $\begin{array}{l}143 \\
150 \\
158 \\
\end{array}$ \\
\hline & 1.50 & 19.81 & 11 & 27 & $\begin{array}{l}0.50 \\
0.75 \\
1.00\end{array}$ & $\begin{array}{l}164 \\
172 \\
180\end{array}$ \\
\hline & 2.50 & 19.83 & 13 & 30 & $\begin{array}{l}0.50 \\
0.75 \\
1.00 \\
\end{array}$ & \begin{tabular}{|l|}
233 \\
243 \\
253 \\
\end{tabular} \\
\hline \multirow{3}{*}{5} & 1.00 & 19.6 & 10 & 28 & $\begin{array}{l}0.50 \\
0.75 \\
1.00 \\
\end{array}$ & $\begin{array}{l}147 \\
155 \\
163 \\
\end{array}$ \\
\hline & 1.50 & 19.81 & 11 & 29 & $\begin{array}{l}0.50 \\
0.75 \\
1.00\end{array}$ & $\begin{array}{l}173 \\
182 \\
191\end{array}$ \\
\hline & 2.50 & 19.83 & 11 & 32 & $\begin{array}{l}0.50 \\
0.75 \\
1.00 \\
\end{array}$ & $\begin{array}{l}211 \\
221 \\
230 \\
\end{array}$ \\
\hline \multirow{3}{*}{6} & 1.00 & 19.6 & 9 & 26 & $\begin{array}{l}0.50 \\
0.75 \\
1.00 \\
\end{array}$ & $\begin{array}{l}129 \\
136 \\
143 \\
\end{array}$ \\
\hline & 1.50 & 19.81 & 10 & 29 & $\begin{array}{l}0.50 \\
0.75 \\
1.00\end{array}$ & $\begin{array}{l}162 \\
170 \\
179\end{array}$ \\
\hline & 2.50 & 19.83 & 12 & 31 & 0.50 & 222 \\
\hline
\end{tabular}


Evaluation of Sub-Soil Geotechnical Properties for Shallow Foundation and Pavement Design ....

\begin{tabular}{|c|c|c|c|c|c|c|}
\hline & & & & & $\begin{array}{l}0.75 \\
1.00 \\
\end{array}$ & $\begin{array}{l}232 \\
241 \\
\end{array}$ \\
\hline \multirow{3}{*}{7} & 1.00 & 19.6 & 10 & 28 & $\begin{array}{l}0.50 \\
0.75 \\
1.00\end{array}$ & $\begin{array}{l}147 \\
155 \\
163\end{array}$ \\
\hline & 1.50 & 19.81 & 12 & 30 & $\begin{array}{l}0.50 \\
0.75 \\
1.00 \\
\end{array}$ & $\begin{array}{l}191 \\
200 \\
210\end{array}$ \\
\hline & 2.50 & 19.83 & 12 & 31 & $\begin{array}{l}0.50 \\
0.75 \\
1.00\end{array}$ & $\begin{array}{l}222 \\
232 \\
241\end{array}$ \\
\hline \multirow{3}{*}{8} & 1.00 & 19.6 & 11 & 28 & $\begin{array}{l}0.50 \\
0.75 \\
1.00 \\
\end{array}$ & $\begin{array}{l}157 \\
165 \\
173 \\
\end{array}$ \\
\hline & 1.50 & 19.81 & 9 & 29 & $\begin{array}{l}0.50 \\
0.75 \\
1.00\end{array}$ & $\begin{array}{l}152 \\
160 \\
167\end{array}$ \\
\hline & 2.50 & 19.83 & 11 & 33 & $\begin{array}{l}0.50 \\
0.75 \\
1.00\end{array}$ & $\begin{array}{l}216 \\
226 \\
236\end{array}$ \\
\hline
\end{tabular}

Table 3: Total Consolidation Settlement

\begin{tabular}{|c|c|}
\hline Foundation breadth, B (m) & $\begin{array}{c}\text { Settlement } \rho \mathrm{v} \\
(\mathrm{mm})\end{array}$ \\
\hline 1.0 & 9.28 \\
1.5 & 13.92 \\
2.0 & 18.56 \\
2.5 & 23.20 \\
3.0 & 27.84 \\
\hline
\end{tabular}

Table 4a: Average CBR value at Section 1

\begin{tabular}{|c|c|c|c|c|}
\hline $\begin{array}{c}\text { Depth } \\
(\mathrm{mm})\end{array}$ & $\begin{array}{c}\text { No. of } \\
\text { Blow }\end{array}$ & $\begin{array}{c}\text { Penetration } \\
\text { Index } \\
(\mathrm{mm} / \mathrm{Blow})\end{array}$ & $\log (\mathrm{CBR})$ & $\begin{array}{c}\text { CBR } \\
(\%)\end{array}$ \\
\hline 0 & 0 & 28.57 & 0.94 & 8.73 \\
200 & 7 & 25.00 & 1.00 & 10.05 \\
400 & 8 & 25.00 & 1.00 & 10.05 \\
600 & 8 & 28.57 & 0.94 & 8.73 \\
800 & 7 & 25.00 & 1.00 & 10.05 \\
1000 & 8 & 20.00 & 1.10 & 12.73 \\
1200 & 10 & 20.00 & 1.10 & 12.73 \\
1400 & 10 & 18.18 & 1.15 & 14.08 \\
1600 & 11 & 16.67 & 1.19 & 15.43 \\
1800 & 12 & 16.67 & 1.19 & 15.43 \\
2000 & 12 & & & \\
\hline
\end{tabular}

Table 4c: Average CBR value at Section 3

\begin{tabular}{|c|c|c|c|c|}
\hline $\begin{array}{c}\text { Depth } \\
(\mathrm{mm})\end{array}$ & $\begin{array}{c}\text { No. of } \\
\text { Blow }\end{array}$ & $\begin{array}{c}\text { Penetration } \\
\text { Index } \\
(\mathrm{mm} / \mathrm{Blow})\end{array}$ & $\log (\mathrm{CBR})$ & $\begin{array}{c}\text { CBR } \\
(\%)\end{array}$ \\
\hline 0 & 0 & 40.00 & 0.79 & 6.12 \\
200 & 5 & 28.57 & 0.94 & 8.73 \\
400 & 7 & 25.00 & 1.00 & 10.05 \\
600 & 8 &
\end{tabular}

Table 4b: Average CBR value at Section 2

\begin{tabular}{|c|c|c|c|c|}
\hline $\begin{array}{c}\text { Depth } \\
(\mathrm{mm})\end{array}$ & $\begin{array}{c}\text { No. of } \\
\text { Blow }\end{array}$ & $\begin{array}{c}\text { Penetration } \\
\text { Index } \\
(\mathrm{mm} / \text { Blow })\end{array}$ & $\log (\mathrm{CBR})$ & $\begin{array}{c}\text { CBR } \\
(\%)\end{array}$ \\
\hline 0 & 0 & 18.18 & 1.15 & 14.08 \\
200 & 11 & 25.00 & 1.00 & 10.05 \\
400 & 8 & 25.00 & 1.00 & 10.05 \\
600 & 8 & 25.00 & 1.00 & 10.05 \\
800 & 8 & 22.22 & 1.06 & 11.39 \\
1000 & 9 & 22.22 & 1.06 & 11.39 \\
1200 & 9 & 16.67 & 1.19 & 15.43 \\
1400 & 12 & 15.38 & 1.23 & 16.80 \\
1600 & 13 & 15.38 & 1.23 & 16.80 \\
1800 & 13 & 14.29 & 1.26 & 18.17 \\
2000 & 14 & &
\end{tabular}

Table 4d: Average CBR value at Section 4

\begin{tabular}{|c|c|c|c|c|}
\hline $\begin{array}{c}\text { Depth } \\
(\mathrm{mm})\end{array}$ & $\begin{array}{c}\text { No. of } \\
\text { Blow }\end{array}$ & $\begin{array}{c}\text { Penetration } \\
\text { Index } \\
(\mathrm{mm} / \text { Blow })\end{array}$ & $\log (\mathrm{CBR})$ & $\begin{array}{c}\text { CBR } \\
(\%)\end{array}$ \\
\hline 0 & 0 & & 0.94 & 8.73 \\
200 & 7 & 28.57 & 0.94 & 8.73 \\
400 & 7 & 28.57 & 1.00 & 10.05 \\
600 & 8 & 25.00 &
\end{tabular}


Evaluation of Sub-Soil Geotechnical Properties for Shallow Foundation and Pavement Design ....

\begin{tabular}{|c|c|c|c|c|}
800 & 8 & 25.00 & 1.00 & 10.05 \\
1000 & 6 & 33.33 & 0.87 & 7.42 \\
1200 & 6 & 33.33 & 0.87 & 7.42 \\
1400 & 10 & 20.00 & 1.10 & 12.73 \\
1600 & 11 & 18.18 & 1.15 & 14.08 \\
1800 & 11 & 18.18 & 1.15 & 14.08 \\
2000 & 12 & 16.67 & 1.19 & 15.43 \\
\hline
\end{tabular}

Table 4e: Average CBR value at Section 5

\begin{tabular}{|c|c|c|c|c|}
\hline $\begin{array}{c}\text { Depth } \\
(\mathrm{mm})\end{array}$ & $\begin{array}{c}\text { No. of } \\
\text { Blow }\end{array}$ & $\begin{array}{c}\text { Penetration } \\
\text { Index } \\
(\mathrm{mm} / \mathrm{Blow})\end{array}$ & $\log (\mathrm{CBR})$ & $\begin{array}{c}\text { CBR } \\
(\%)\end{array}$ \\
\hline 0 & 0 & 40.00 & 0.79 & 6.12 \\
200 & 5 & 33.33 & 0.87 & 7.42 \\
400 & 6 & 40.00 & 0.79 & 6.12 \\
600 & 5 & 40.00 & 0.79 & 6.12 \\
800 & 5 & 33.33 & 0.87 & 7.42 \\
1000 & 6 & 40.00 & 0.79 & 6.12 \\
1200 & 5 & 33.33 & 0.87 & 7.42 \\
1400 & 6 & 28.57 & 0.94 & 8.73 \\
1600 & 7 & 28.57 & 0.94 & 8.73 \\
1800 & 7 & 28.57 & 0.94 & 8.73 \\
2000 & 7 & & & \\
\hline
\end{tabular}

\begin{tabular}{|c|c|c|c|c|}
800 & 9 & 22.22 & 1.06 & 11.39 \\
1000 & 9 & 22.22 & 1.06 & 11.39 \\
1200 & 11 & 18.18 & 1.15 & 14.08 \\
1400 & 12 & 16.67 & 1.19 & 15.43 \\
1600 & 12 & 16.67 & 1.19 & 15.43 \\
1800 & 13 & 15.38 & 1.23 & 16.80 \\
2000 & 13 & 15.38 & 1.23 & 16.80 \\
\hline
\end{tabular}

Table 4f: Average CBR value at Section 6

\begin{tabular}{|c|c|c|c|c|}
\hline $\begin{array}{c}\text { Depth } \\
(\mathrm{mm})\end{array}$ & $\begin{array}{c}\text { No. of } \\
\text { Blow }\end{array}$ & $\begin{array}{c}\text { Penetration } \\
\text { Index } \\
(\mathrm{mm} / \mathrm{Blow})\end{array}$ & $\log (\mathrm{CBR})$ & $\begin{array}{c}\text { CBR } \\
(\%)\end{array}$ \\
\hline 0 & 0 & 33.33 & 0.87 & 7.42 \\
200 & 6 & 22.22 & 1.06 & 11.39 \\
400 & 9 & 20.00 & 1.10 & 12.73 \\
600 & 10 & 18.18 & 1.15 & 14.08 \\
800 & 11 & 16.67 & 1.19 & 15.43 \\
1000 & 12 & 15.38 & 1.23 & 16.80 \\
1200 & 13 & 14.29 & 1.26 & 18.17 \\
1400 & 14 & 14.29 & 1.26 & 18.17 \\
1600 & 14 & 14.29 & 1.26 & 18.17 \\
1800 & 14 & 14.29 & 1.26 & 18.17 \\
2000 & 14 & \multicolumn{2}{|c|}{} \\
\hline
\end{tabular}

Table 4g: Average CBR value at Section 7

\begin{tabular}{|c|c|c|c|c|}
\hline $\begin{array}{c}\text { Depth } \\
(\mathrm{mm})\end{array}$ & $\begin{array}{c}\text { No. of } \\
\text { Blow }\end{array}$ & $\begin{array}{c}\text { Penetration } \\
\text { Index } \\
\text { (mm/Blow) }\end{array}$ & $\log (\mathrm{CBR})$ & $\begin{array}{c}\text { CBR } \\
(\%)\end{array}$ \\
\hline 0 & 0 & 33.33 & 0.87 & 7.42 \\
200 & 6 & 40.00 & 0.79 & 6.12 \\
400 & 5 & 33.33 & 0.87 & 7.42 \\
600 & 6 & 33.33 & 0.87 & 7.42 \\
800 & 6 & 28.57 & 0.94 & 8.73 \\
1000 & 7 & 25.00 & 1.00 & 10.05 \\
1200 & 8 & 22.22 & 1.06 & 11.39 \\
1400 & 9 & 18.18 & 1.15 & 14.08 \\
1600 & 11 & 16.67 & 1.19 & 15.43 \\
1800 & 12 & 16.67 & 1.19 & 15.43 \\
2000 & 12 & & &
\end{tabular}

Table 4h: Average CBR value at Section 8

\begin{tabular}{|c|c|c|c|c|}
\hline $\begin{array}{c}\text { Depth } \\
(\mathrm{mm})\end{array}$ & $\begin{array}{c}\text { No. of } \\
\text { Blow }\end{array}$ & $\begin{array}{c}\text { Penetration } \\
\text { Index } \\
(\mathrm{mm} / \mathrm{Blow})\end{array}$ & $\log (\mathrm{CBR})$ & $\begin{array}{c}\mathrm{CBR} \\
(\%)\end{array}$ \\
\hline 0 & 0 & 33.33 & 0.87 & 7.42 \\
200 & 6 & 28.57 & 0.94 & 8.73 \\
400 & 7 & 25.00 & 1.00 & 10.05 \\
600 & 8 & 22.22 & 1.06 & 11.39 \\
800 & 9 & 22.22 & 1.06 & 11.39 \\
1000 & 9 & 18.18 & 1.15 & 14.08 \\
1200 & 11 & 18.18 & 1.15 & 14.08 \\
1400 & 11 & 16.67 & 1.19 & 15.43 \\
1600 & 12 & 18.18 & 1.15 & 14.08 \\
1800 & 11 & 16.67 & 1.19 & 15.43 \\
\hline 2000 & 12 & &
\end{tabular}

